\title{
The Effectiveness of Dialectical Behavioral Therapy (DBT) on Emotion Regulation and Impulse Control of Soldiers with a Self- Reporting Experience
}

\begin{abstract}
Introduction: The purpose of the present study was to investigate the effectiveness of dialectical behavior therapy on emotion regulation and impulsivity control in self-reported soldiers.

Methods: In a quasi-experimental research design, 20 soldiers with self-harm symptoms were selected based on available sampling criteria and randomly divided into two experimental groups $(10$ subjects). And the control group $(\mathrm{n}=10)$. Experimental group received 12 sessions of dialectical behavior therapy intervention in both groups. Participants in both groups were evaluated by Barratt Impulsiveness Scale (BIS-11), Garnefsky Cognitive-Emotional Regulation Questionnaire (CERQ-P), and the Self-Behavior Questionnaire Gratz (GISB) in three stages of pre-test, post-test, and 1-month follow-up. Data were analyzed by repeated measure ANOVA and SPSS software.

Results: The results showed that group-based dialectical behavior therapy had a positive effect on the modification of emotion regulation strategies in soldiers with a history of self-injury and group dialectic behavior therapy training had a positive effect on reducing impulsivity. It has also been effective on some subscales of emotion regulation and impulsivity of soldiers with a history of self-harm.

Conclusion: The results showed that dialectical behavior therapy has a significant effect on increasing emotion regulation and impulsive control of soldiers with a history of self-harm.
\end{abstract}

Keywords: Dialectical behavior therapy, Emotion Regulation, Impulsive Control, Self-harm, Soldier

\footnotetext{
Affiliations

1- Master of clinical Psychology, Department of Clinical Psychology, Medicine Faculty, Aja University of Medical Sciences, Tehran, Iran. 2- Assistant Professor, Department of Clinical Psychology, Medicine Faculty, Aja University of Medical Sciences, Tehran, Iran.

Corresponding Author: dabaghi_44@yahoo.com

3- Associate Professor, Behavioral Sciences Research Center, Department of Clinical Psychology, Faculty of Medicine, Baqiyatallah University of Medical Sciences, Tehran, Iran
}

Article Info

Authors:

Mohammadi $\mathrm{A}^{1} \oplus$

Dabaghi $\mathrm{P}^{2 *} \odot$

Ahmadi Tahor-Soltani $\mathrm{M}^{3} \odot$

Received: 2020.10.6

Accepted: 2020.10.23

E-Published: 2020.11.20

\section{Citation Subjects:}

Behavior Therapy,

Conditioning Therapy,

Behavior Treatment,

Emotions, Emotional Self-

Regulation, Self-Injury, Self-

Destructive Behavior,

Nonsuicidal Self Injury,

Intentional Self Injury,

Military, Army Personnel,

Armed Forces Personnel 
فصلنامه يرستار و يزشك در رزم / ياييز 99 / سال هشتم

\section{اثربخشى رفتاردرمانى ديالكتيكى (DBT) بر تنظيم هيجان و كنترل تكانش سربازان داراى سابقه خودزنى}

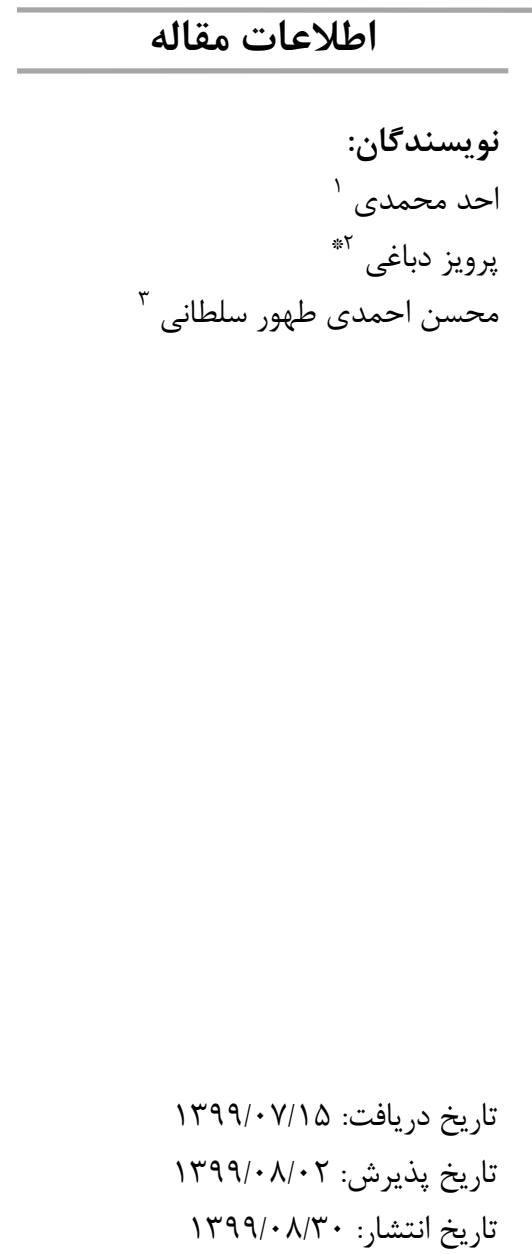

مقدمه: هدف مطالعه حاضر، بررسى اثربخشى رفتاردرمانى ديالكتيكى بر تنظيم هيجان و كنترل تكانش

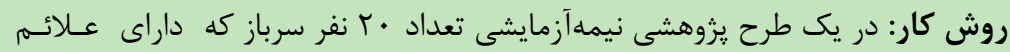

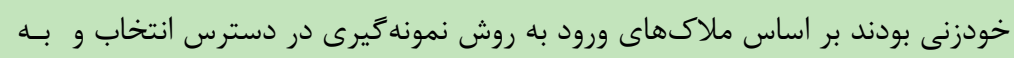

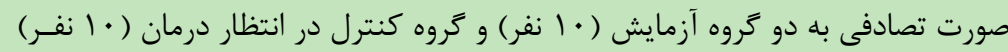

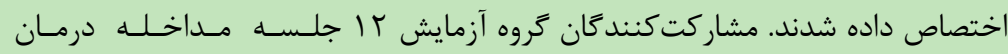

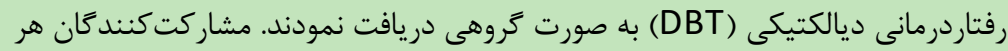

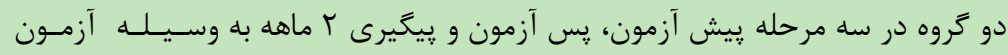

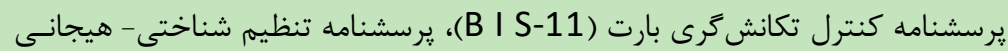

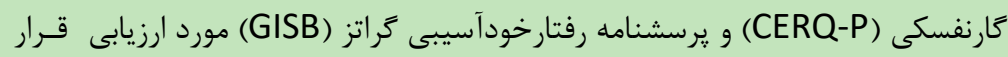

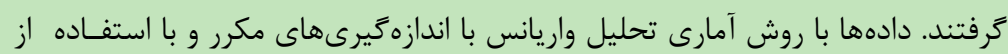

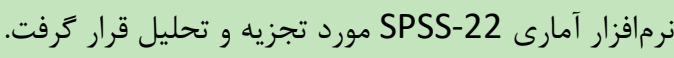

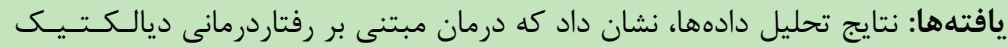

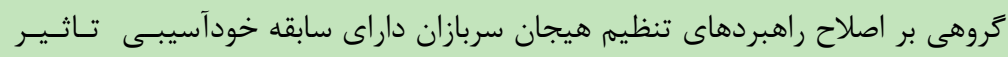

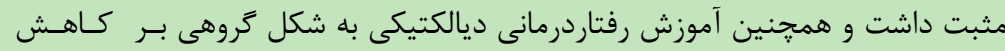

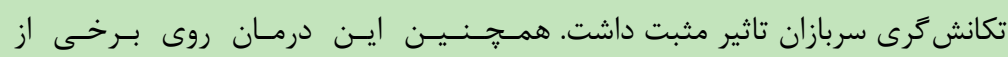

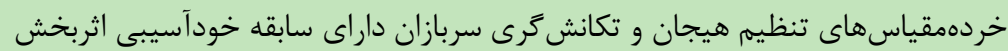
بوده است. بحث و نتيجه كيرى: نتايج نشان داد كه رفتاردرمانى ديالكتيكى به طور معنـادارى در

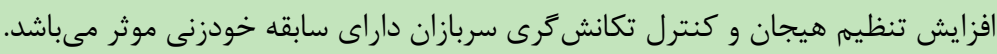

وازًَان كليدى: رفتاردرمانى ديالكتيكى، تنظيم هيجان، كنترل تكانش سرباز
عناوين ارجاعى:

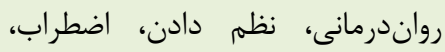

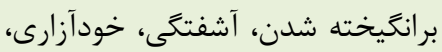

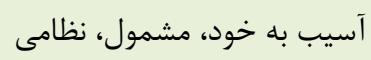

وابستكى سازمانى نويسندكان

1- كَروه روانشناسى بالينى، دانشكده يزشكى، دانشعاه علوم يزشكى ارتش جمهورى اسلامى ايـران،

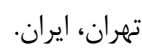

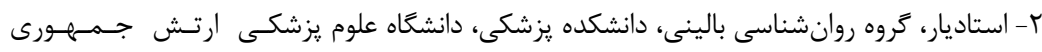

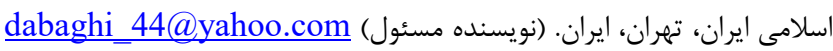

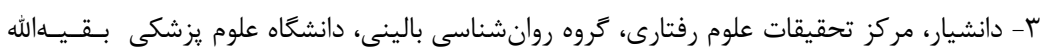

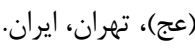


تنظيم هيجان به عنوان فرآيندهايى كه از طريق آنسهـا

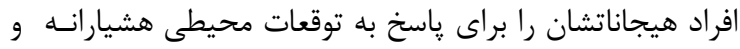

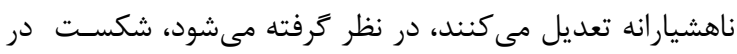

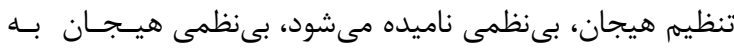

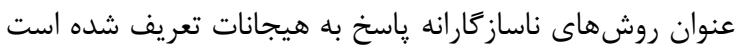

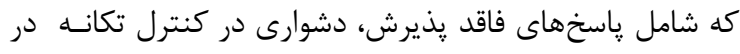

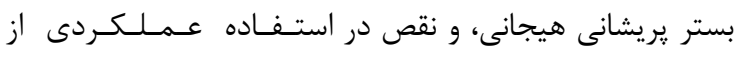

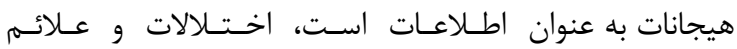

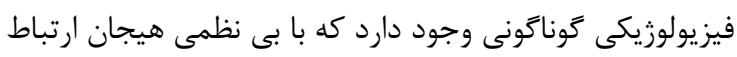

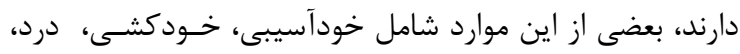

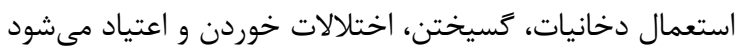

يكى ديكر از عواملى كه موجب ميىشود خودآسيبى در

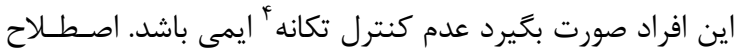

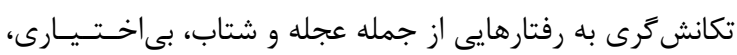

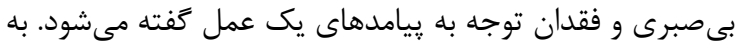

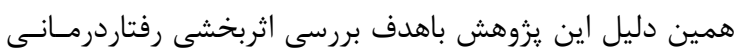

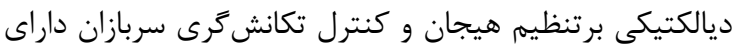

سابقه خودزنى اجرا شد (9).

روش كار

طرح يزوهش حاضر به روش نيمهآزمايشى با طرح بِيشآزمـون،

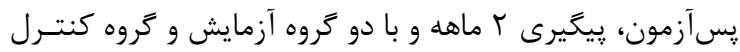

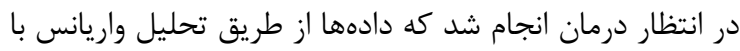

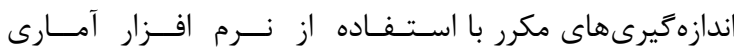

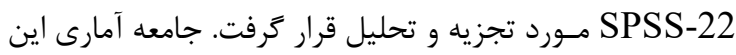
يزوهش شامل كليه سربازان داراى سابقه خودآسيبى يك يخـان نظامى در سال ع بـا بود.

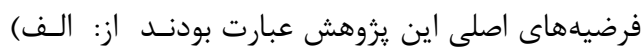

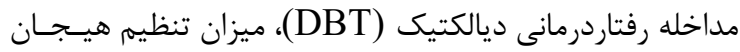

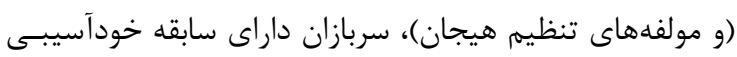

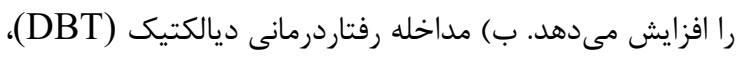
ميزان تكانش

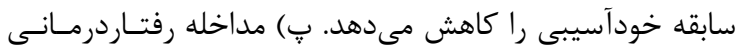

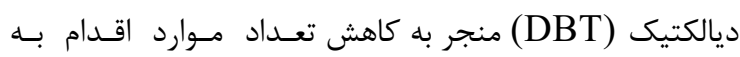

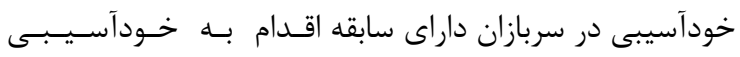
مى كردد.

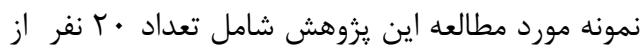

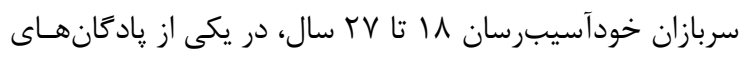

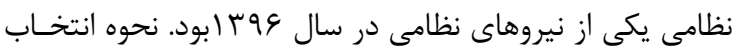

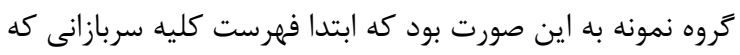

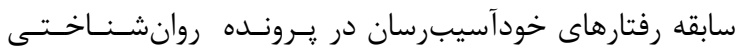

4- Impulse Control
مقدمه

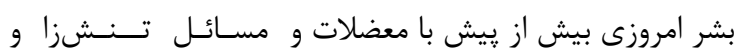

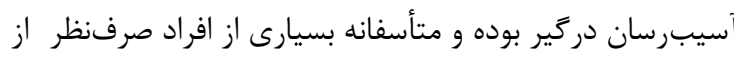

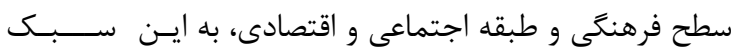

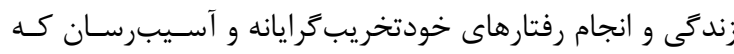

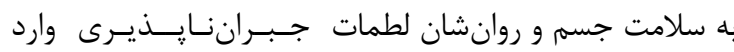

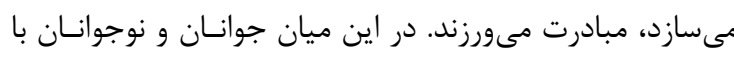

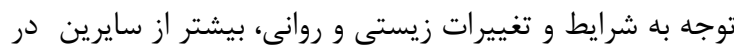

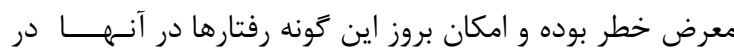

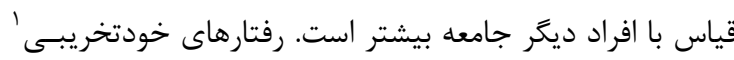

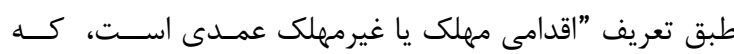

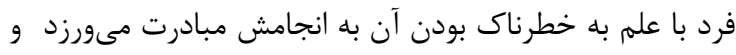

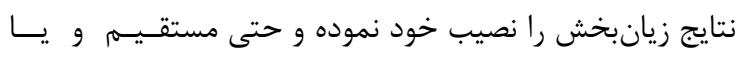

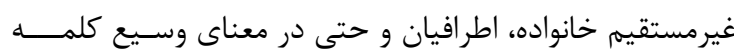

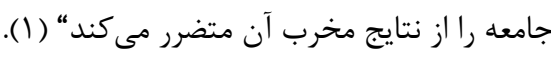

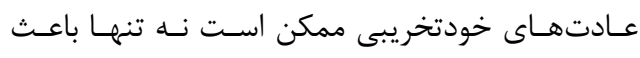

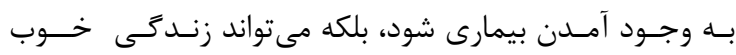

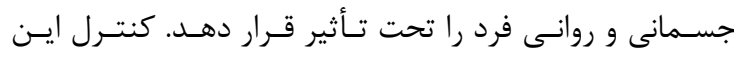

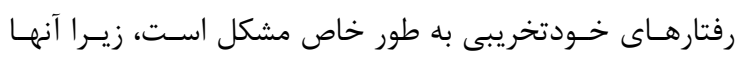

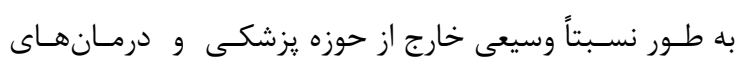

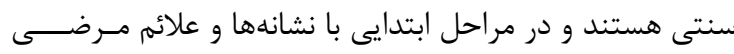

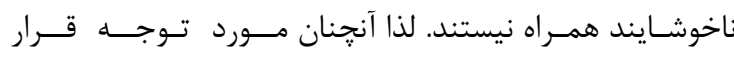

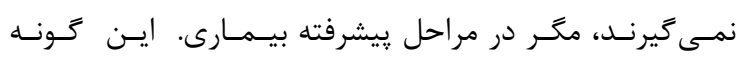

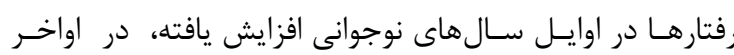

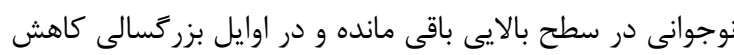

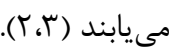

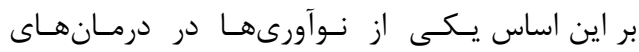

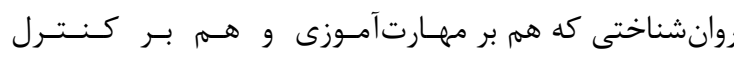
تكانش

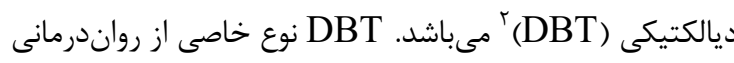

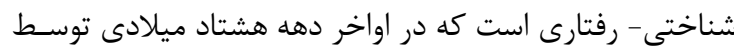

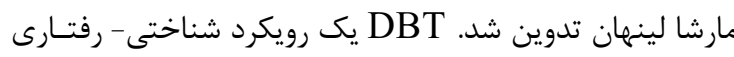

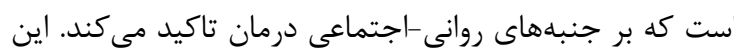

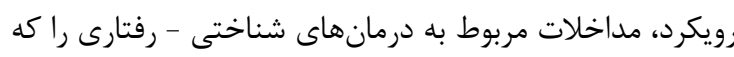

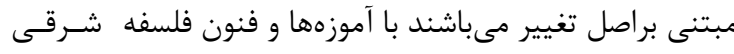

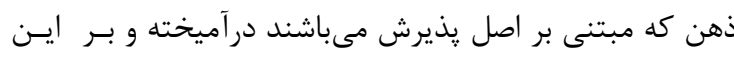

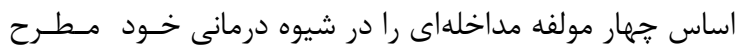

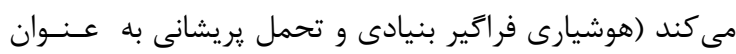

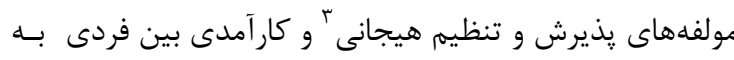

عنوان مولف هاى تغيير (Y).

1- Self Injury

2- Dialectical Behavioral Therapy-DBT

3- Emotion Regulation 
درمانهـاى انجام شده تابه حال و سوءمصرف مواد مخدر توسط

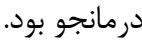

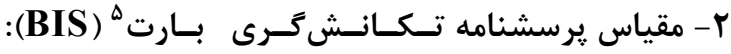

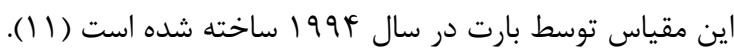

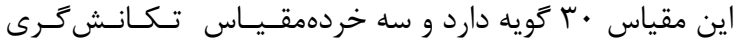

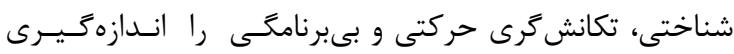

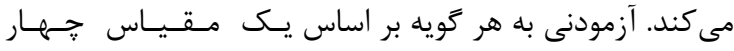

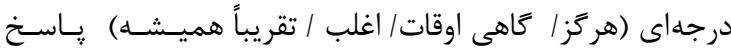

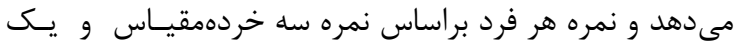
نمره كل محاسبه مى شود (9). r- يرسشنامه تنظيم شناختى - هيجانى (CERQ-P)

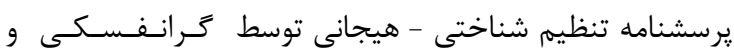

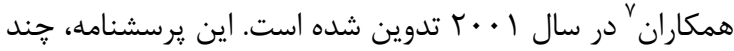

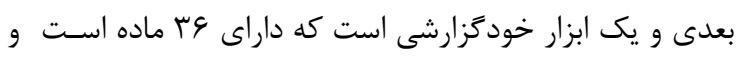

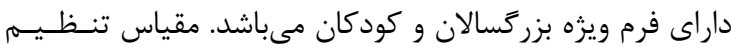

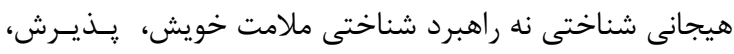

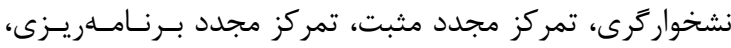

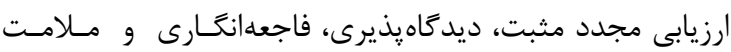

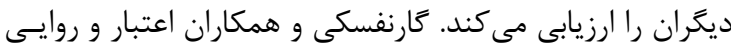

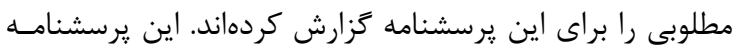

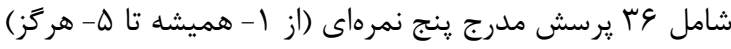

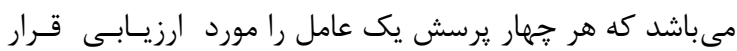

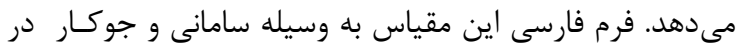
سال ع بـ امورد اعتباريابى قرار گرفته است (• • (1).

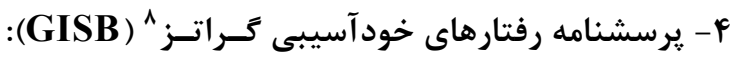

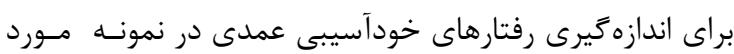

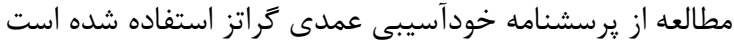

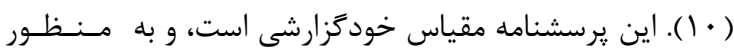

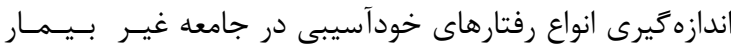

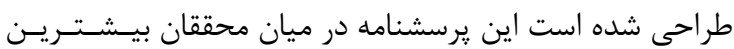
توجه و يزوهش را به خود جلب كرده است. آزمون شـامـل 19

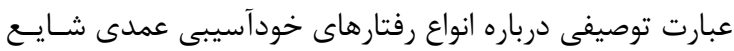

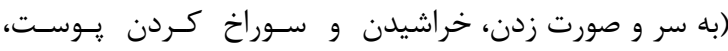

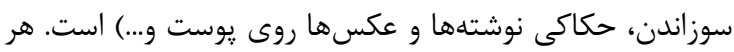

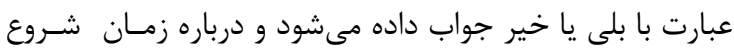

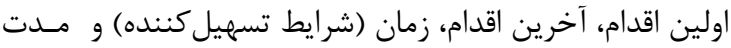

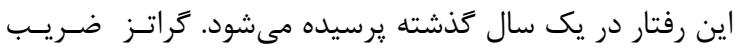

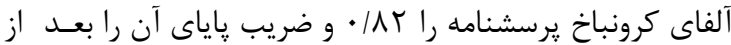

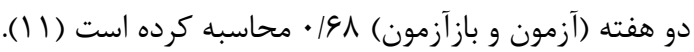

5- Barratt Impulsiveness Scale-BIS

6- Cognitive Emotion Regulation Questionnaire-CERQ

7- Granovsky et al

8- Gratis Intentional self-injury Behavior Questionnaire-GISB

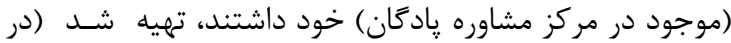

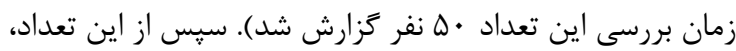

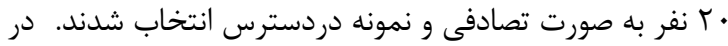

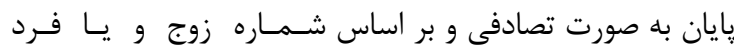

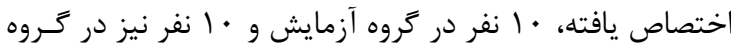

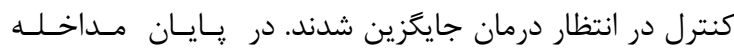

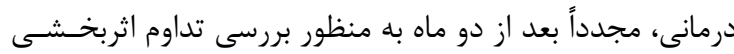

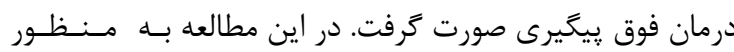

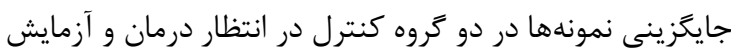

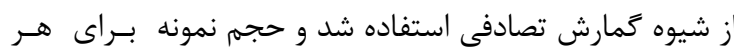

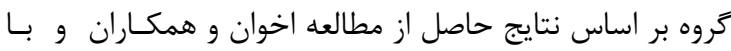

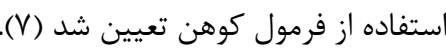
ملاك هاى ورود براى شركت در اين مطالعه نيز شامـل:

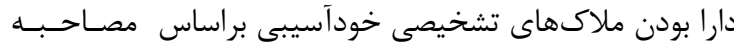

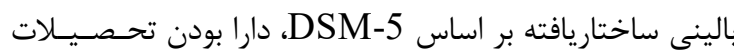

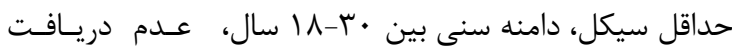

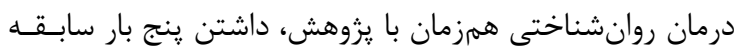

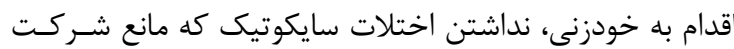
در درمان شود كه توسط مصاحبه تشخيصى مورد بررسى قـر تدرار

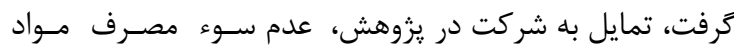

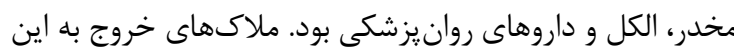

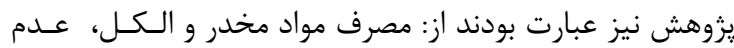

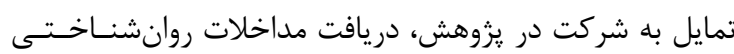

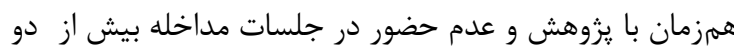
جلسه.

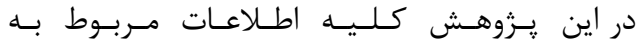
مشاركت كنند

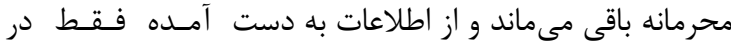

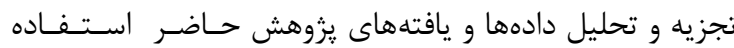

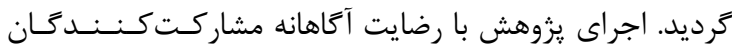

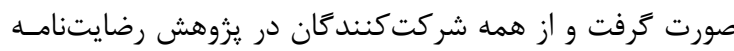

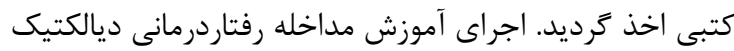

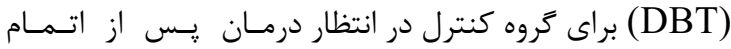
ئروهش صورت ترفت. لازم به ذكر است اين مطالعه در كميته اخلاق دانشعـاه

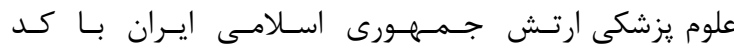
IR.AJAUMS.REC.1396.37 به تصويب رسيده است.

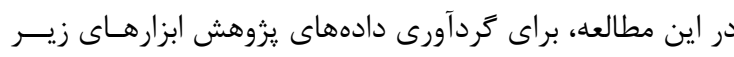

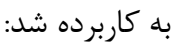

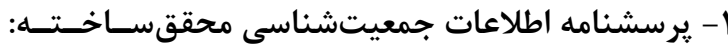

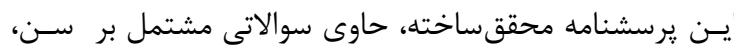

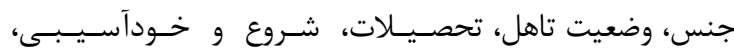


متناسب با رفتارهاى ضرخاشكرانه طراحى شده اسـت (جـدول

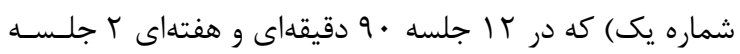

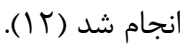

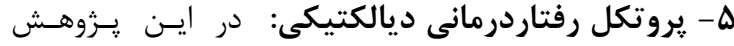

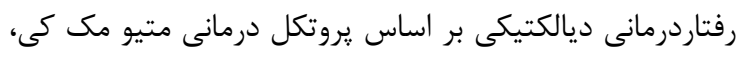

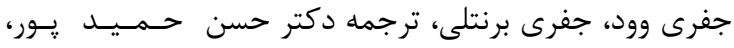

\section{جدول ا: بروتكل مداخله رفتار درمانى ديالكتيكى}

\begin{tabular}{|c|c|}
\hline 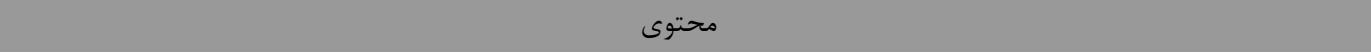 & جلسه \\
\hline آشنايى اوليه و معرفى متقابل افراد به يكديكر، معرفى رفتاردرمانى ديالكتيكى و اهداف آن. & اول \\
\hline آموزش تصميمخيرى براساس ذهن خردمند، يذيرش بنيادين، قضاوت و برجسبهها. & دوم \\
\hline آموزش يذيرش بنيادين، توجه بركردانى از رفتارهاى خودجرحى، توجه بركردانى از طريق فعاليتهاى لذتبخش. & 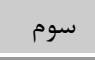 \\
\hline آموزش توجهبرَردانى از طريق معطوف كردن توجه به كار يا موضوعى ديكر. & جهارم \\
\hline آز طوزش توجهبر آردانى از طريق تركى موقعيت، توجه بركردانى از طريق تكاليف و كارهاى روزمره و همجنين آموزش توجهبركردانى & ينجم \\
\hline آموزش تصويرسازى از مكان امن و كشف ارزش ها و همجنين آموزش شناسايى قدرت برتر و ارتباط بهتر با قدرت برتر و تعيين وقت & ششم \\
\hline آموزش زندكى در زمان حال، استفاده از افكار مقابلهاى خودتشويق گرايانه. & هفتم \\
\hline آموزش يذيرش بنيادين، خودَّيى هاى تأييدگرايانه و راهبردهاى مقابلهاى جديد. & هشتم \\
\hline آموزش قضاوت نكردن و تجارب روزمره و ارتباط آكاهانه با ديكران. & نקه \\
\hline 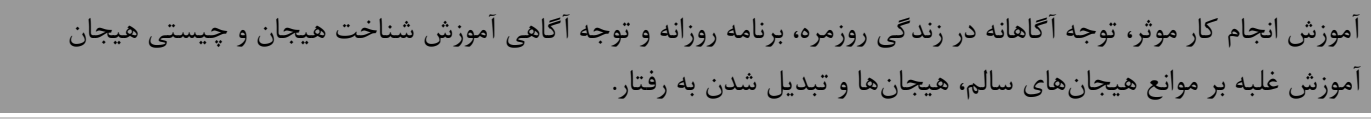 & دهم \\
\hline آموزش كاهش آسيبذيذى جسمى در برابرهيجانهاى آشفتهساز. & يازدهم \\
\hline جمعبندى، تمرين و مرور خده جلستن بدون قضاوت درباره خويشتن آموزش رويارويى با هيجان، عمل كردن برخلاف اميال شديد هيجانى. & دوازدهم \\
\hline
\end{tabular}

سوزن در بدن (ז (ا؛ • . ./) و خوردن مواد خطرناك (• (؛ • •./)

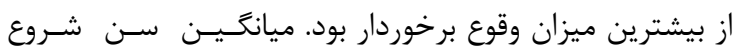

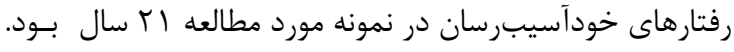

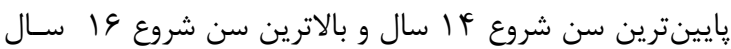

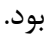

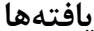
در هر دو كروه آزمايش و كنترل در انتظار درمان، تعداد 9 نــــــــ

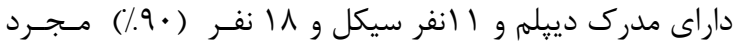

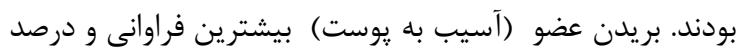

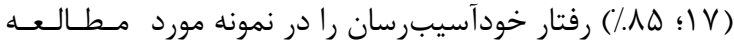

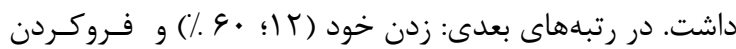

\section{جدول ז: ميانكَين و انحراف معيار نمرههاى متغير تنظيم هيجان به تفكيك تروهها و مراحل آزمون}

\begin{tabular}{|c|c|c|c|c|c|c|c|}
\hline \multicolumn{2}{|c|}{ ييخيرى } & \multicolumn{2}{|c|}{ يس آزمون } & \multicolumn{2}{|c|}{ ييش آزمون } & \multirow{2}{*}{\multicolumn{2}{|c|}{ متغير كروه }} \\
\hline انحراف معيار & ميانگَين & انحراف معيار & ميانَين & انحراف معيار & ميانگين & & \\
\hline$F / 9 F$ & $111 / 9$. & $F / \Delta 9$ & $\| f / 9$. & $\mathrm{V} / \cdot \cdot$ & $9 T / \Lambda$. & آزمايش & \multirow{2}{*}{ ظيم هيجان } \\
\hline$V / 91$ & $q \cdot / v \cdot$ & $9 / 11$ & $9 \cdot 19$. & $g / 4 \wedge$ & $q r / 4$. & كنترل & \\
\hline
\end{tabular}

داشته است. اما اين تغيير براى كروه كنترل در انتظار درمان در هيج يك از مراحل ديده نمىشود.
بافتههاى ارائه شده در جدول فوق نشان مى دهــند، نمره متغيـر

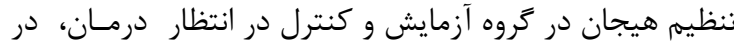

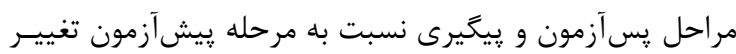


نمودار ا: مقايسه ميانگين متغير تنظيم هيجان در سه مرحله اندازهيرى براى گروههاى مورد مطالعه

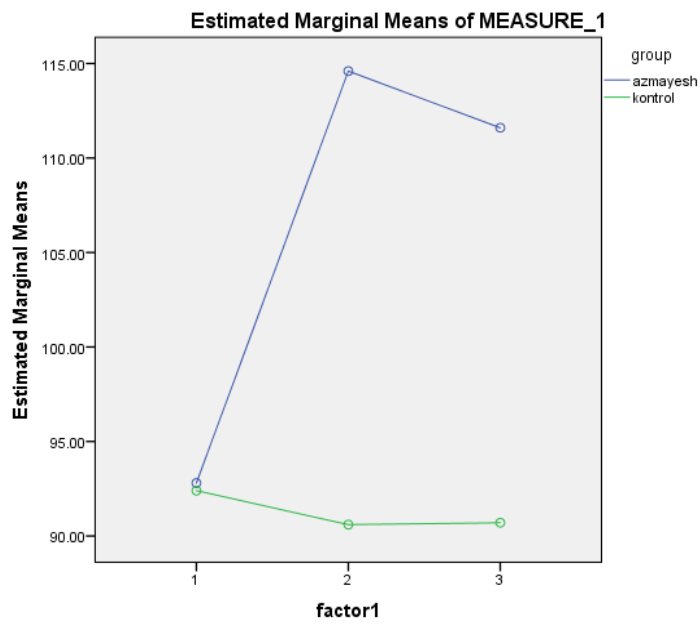

در نمودار خطى شماره يك، در مرحله يسآزمون در مقايسه بـا عروه كنترل در انتظار درمان قابل مشاهده نيست.

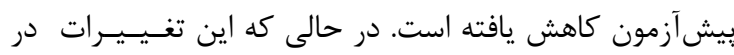

جدول ץ: نتايج تحليل واريانس آميخته متغير تنظيم هيجان براى اثرهاى درون گروهى و بين گروهى مرحله با گروه

\begin{tabular}{|c|c|c|c|c|c|c|c|}
\hline تفكذوراتاى & معنادارى & $\mathbf{F}$ & مجانغَين & درجه آزادى & مجذموع & منبع اثر & منابع تغيير \\
\hline •/VG & $.1 \cdot$ & $\Delta \Lambda / T G$ & $V T I / \cdot r$ & 1 & $V T I / \cdot r$ & مرحله & \multirow{3}{*}{ درون گروهى } \\
\hline \multirow[t]{2}{*}{ • IAT } & .1 & $\Lambda r / V r$ & $1 \cdot \Delta \cdot \mid \varepsilon r$ & 1 & $1 \cdot \Delta \cdot 19 T$ & مرحله با كروه & \\
\hline & & & $\mid r / \Delta F$ & 11 & $r \quad r \Delta / \wedge \Delta$ & خطا & \\
\hline \multirow[t]{2}{*}{$\cdot 190$} & $.1 \cdot$ & TF/TG & TFY./ID & 1 & TFT./ID & مرحله & \multirow{2}{*}{ بين گروهى } \\
\hline & & & १९/८। & 11 & IV৭s/V. & خطا & \\
\hline
\end{tabular}

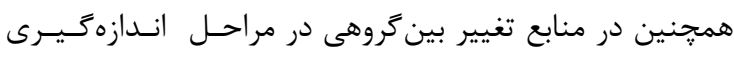

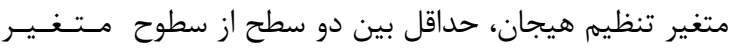

كروهبندى بين گروهيى، تفاوت معنادار وجود دارد . $\mathrm{P}=\cdot / \cdots \mathrm{F}=\mathrm{F} / \mathrm{F} \boldsymbol{C}$
بر اساس نتايج جدول شماره سه در منابع تغيير درون گروهى در

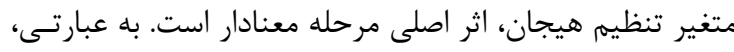

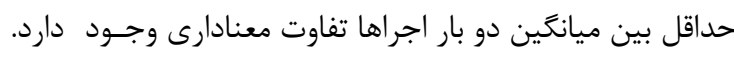

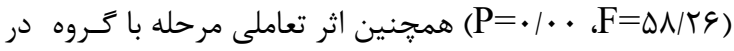
متغير تنظيم هيجان معنادار مىباشد (

جدول f: مقايسه اثرات ساده عامل درون

\begin{tabular}{|c|c|c|c|c|c|c|c|c|}
\hline تفكيكى مجذوراتى & معنادارى & $\mathbf{F}$ & مجانغَين & درجه آزادى & مجذورات & منبع اثر & مقياس & كروه \\
\hline - IV & $\cdot 1 \cdot$ & $\Delta 9 / 9 Y$ & $\Delta \Lambda F / \cdot 1$ & r & $\mid 19 N / \cdot r$ & مرحله & \multirow{2}{*}{ تنظيم هيجان } & \multirow{2}{*}{ آزمايش } \\
\hline & & & $9 / \vee q$ & بs & rDY/G. & خطا & & \\
\hline \multirow[t]{2}{*}{ •/VG } & $\cdot 1 \cdot$ & $\Delta 9 / 8 T$ & $V \mid F / g F$ & r & $\| 19 \mathrm{~N} / \cdot r$ & مرحله & \multirow{2}{*}{ تنظيم هيجان } & \multirow{2}{*}{ كنترل } \\
\hline & & & $11 / 91$ & $r q / 4 T$ & raY/G. & خطا & & \\
\hline
\end{tabular}


شد. جهت ارزيابى بيشفرضهاى ايـن آزمـون و عـدم تـفــاوت

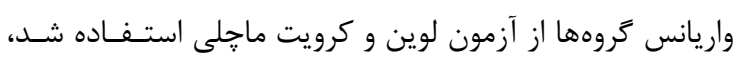

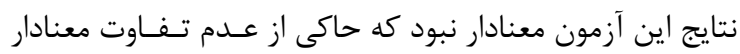

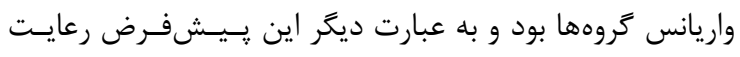

نتايج جدول شماره جهار، نشان مىدهد كه از بين سه مـرحسلـه

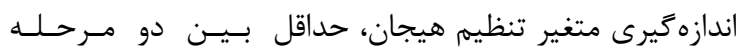

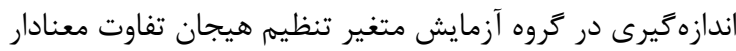
وجود دارد (

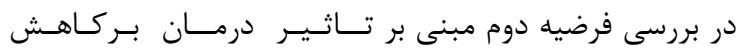
تكانش كرى سربازان از آزمون تحليل واريانس آميخته استـفـاده

جدوله: ميانكَين و انحراف معيار نمره هاى متغير تكانش كرى به تفكيك كروهها و مراحل آزمون

\begin{tabular}{|c|c|c|c|c|c|c|c|}
\hline \multicolumn{2}{|c|}{ ييخيرى } & \multicolumn{2}{|c|}{ يس آزمون } & \multicolumn{2}{|c|}{ بيش آزمون } & \multirow{2}{*}{\multicolumn{2}{|c|}{ متغير تروه }} \\
\hline انحراف معيار & ميانكين & انحراف معيار & ميانكين & انحراف معيار & ميانكَين & & \\
\hline T/9T & $\Delta / / 9$. & $r / r \Delta$ & $F F / T$. & $r / \cdot r$ & $\varphi \Delta / v$ & آزمايش & \\
\hline T/VA & $\Delta \cdot / \Lambda$. & $F / T)$ & $\Delta V / r$. & $r / 9 V$ & $\Delta V / \Lambda$ & كنترل & m \\
\hline
\end{tabular}

تغيير براى كروه كنترل در انتظار درمان در هيج يك از مراحلـ

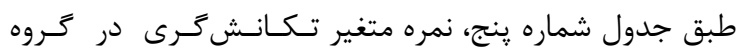
ديده نمى شود.

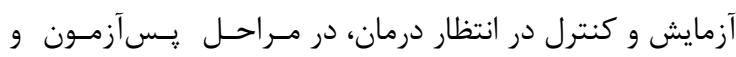

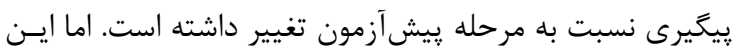

نمودار r: مقايسه ميانگين متغير تكانشترى در سه مرحله اندازهيرى براى تروههاى مورد مطالعه

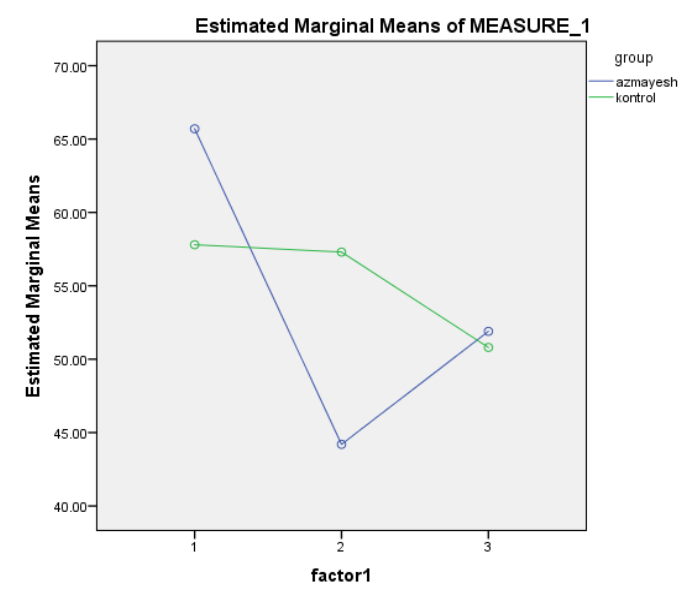

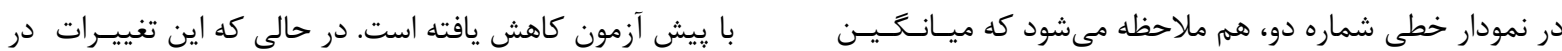

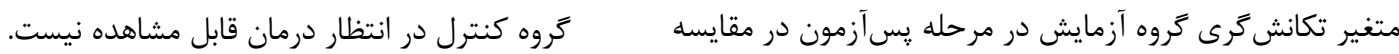

جدول 9 : نتايج تحليل واريانس آميخته متغيرتكانش ترى براى اثرهاى درون تروهى و بين كروهى مرحله با تروه

\begin{tabular}{|c|c|c|c|c|c|c|c|}
\hline تفكيكى مجدراتاى & معنادارى & $\mathbf{F}$ & مجذانكَين & درجه آزادى & مجذمورع & منبع اثر & منابع تغيير \\
\hline .191 &.$/$. & INT/RQ & $1 \cdot 11 / 9$ & 1 & $1 \cdot 11 / 9$ & مرحله & \multirow{3}{*}{ درون كروهى } \\
\hline \multirow[t]{2}{*}{. $/ Q T$} & $\cdot 1 \cdot$ & $19 / 41$ & $\| Q / 9$. & 1 & $\| Q / 9$ & مر حله با كروه & \\
\hline & & & ه/q & 11 & 1.911 & خطا & \\
\hline$\cdot 1 \cdot \Delta$ & rr/. &.$/ 94$ & $r N \cdot 1$ & 1 & $r N \cdot 1$ & كروه & \multirow{2}{*}{ بين كروهى } \\
\hline & & & $r N / 19$ & 11 & $\Delta V \cdot / \Delta \cdot$ & خطا & \\
\hline
\end{tabular}




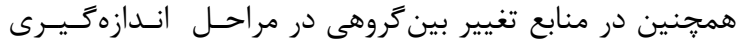

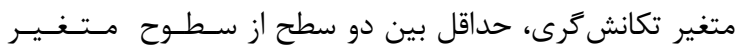

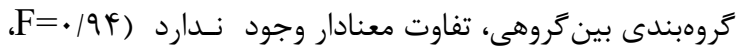
. $\mathrm{P}=\cdot \mathrm{r}$

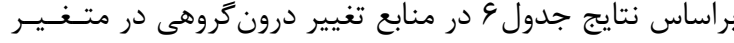

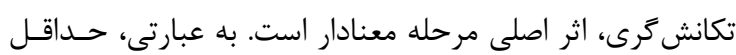

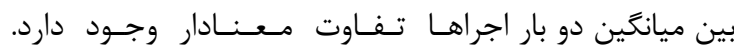

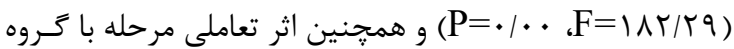

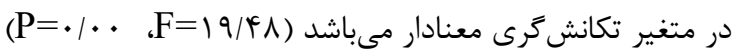

جدول У: مقايسه اثرات ساده عامل درون تروهى به تفكيك كروههاى آزمايش و كنترل در انتظار درمان

\begin{tabular}{|c|c|c|c|c|c|c|c|c|}
\hline تفكيكى مجذراتاى & معنادارى & $\mathbf{F}$ & مجذانغين & درجه آزادى & مجذمورات & منبع اثر & مقياس & كروه \\
\hline.$/ 9$ & 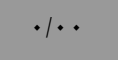 & $199 / 09$ & $V G \Delta / \cdot \varphi$ & r & $\mid \Delta r \cdot / / r$ & مرحله & \multirow{2}{*}{ تكانش } & \multirow{2}{*}{ آزمايش } \\
\hline & & & $F / \Delta \mid$ & rq & $\mid G T / F$. & خطا & & \\
\hline \multirow[t]{2}{*}{$\cdot / 9$} & $\cdot / \cdot$ & $199 / 09$ & $\Lambda F 1 / r q$ & $1 / 11$ & $1 \Delta T \cdot / 1 T$ & مرحله & \multirow{2}{*}{ تكانش } & \multirow{2}{*}{ كنترل } \\
\hline & & & F/१९ & Tr/V & $\mid G T / F$. & خطا & & \\
\hline
\end{tabular}

استفاده شد. جهت ارزيابى بيشفرضهاى ايـن آزمـون و عـــدم

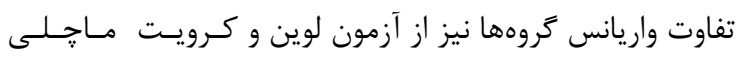

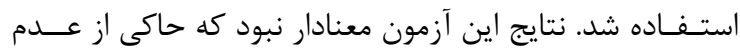

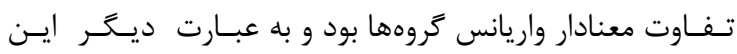

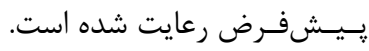

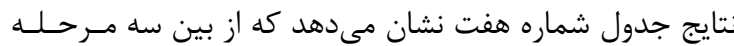

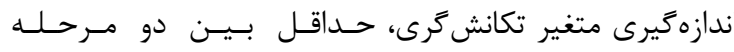

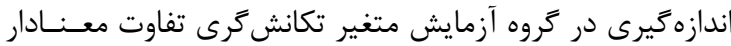

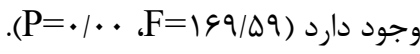

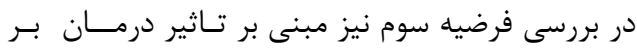

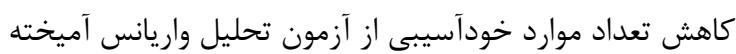

نمودار بّ: مقايسه ميانَين مقياس خودزنى در سه مرحله اندازهيرى براى كروه هاى مورد مطالعه

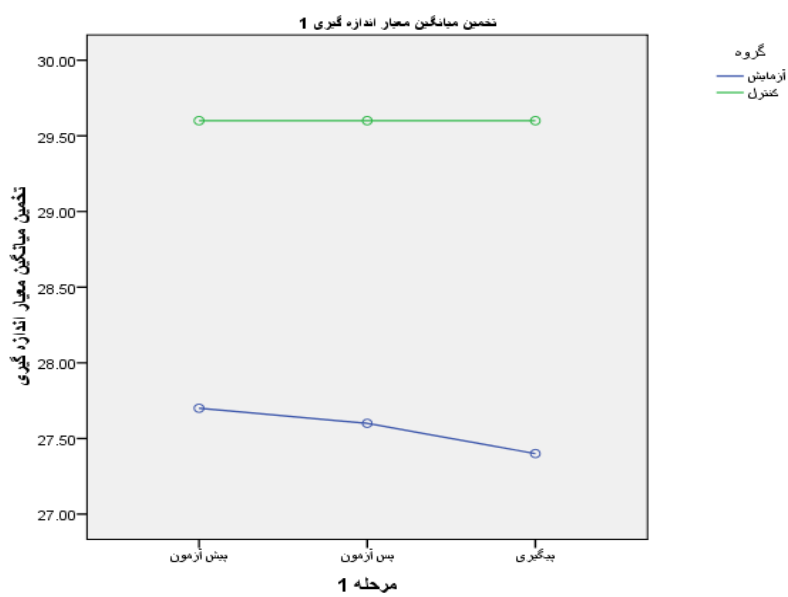

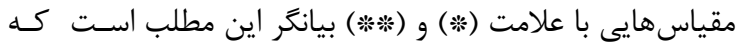

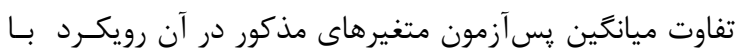

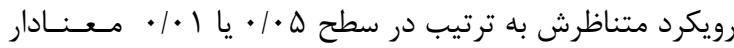

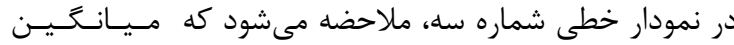

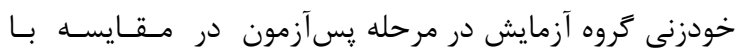

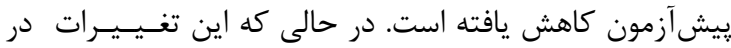

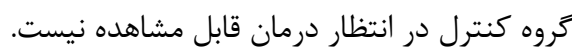

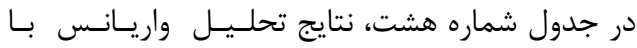

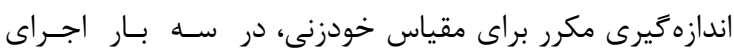

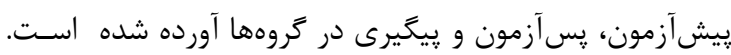


جدول 1: نتايج آناليز واريانس آميخته مقياس خودزنى براى اثرهاى درونتروهى و بينتروهى مرحله با تروه

\begin{tabular}{|c|c|c|c|c|c|c|c|}
\hline تفجذوراتاى & معنادارى & $\mathbf{F}$ & مجانگين & درجه آزادى & مجذموع & منبع اثر & منابع تغيير \\
\hline .1 .99 & $\cdot 1 \cdot r^{*}$ & N/9V & . ITTD & 1 & . /TrD & مرحله & \multirow{3}{*}{ درون گروهى } \\
\hline \multirow[t]{2}{*}{.1 .99} & $\cdot / \cdot \varphi^{*}$ & N/9V & - ITTA & 1 & - ITTD & مرحله با كروه & \\
\hline & & & .1114 & 11 & $\tau / \cdot \Delta$ & خطا & \\
\hline \multirow[t]{2}{*}{.$/ 1 \pi \Delta$} & .1111 & $r|\Lambda|$ & GY/.1 & 1 & GY/. 1 & كروه & \multirow{2}{*}{ بين گروهى } \\
\hline & & & $T Y / . G$ & 11 & rqV/r & خطا & \\
\hline
\end{tabular}

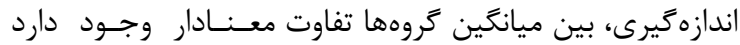

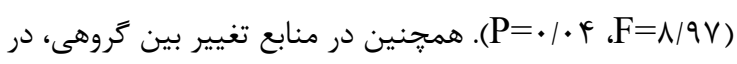

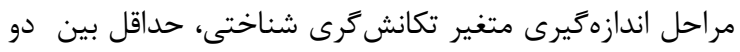

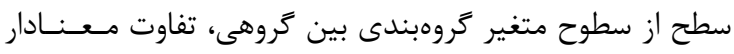
وجود ندارد (P=111/ · F
بر اساس نتايج جدول شماره هشت، درمنابع تغيير درون كروهى إنى

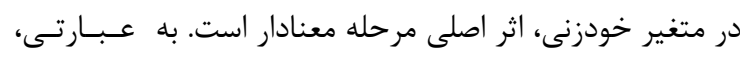

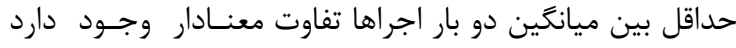

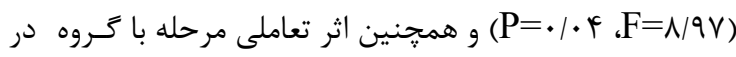

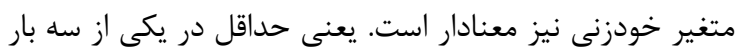

جدول 9: مقايسه اثرات ساده عامل درون كروهى به تفكيك كروههاى آزمايش و كنترل در انتظار درمان

\begin{tabular}{|c|c|c|c|c|c|c|c|c|}
\hline تفكيكى & معنادارى & $\mathbf{F}$ & مجذانكَين & درجه آزادى & مجذورات & منبع اثر & مقياس & تروه \\
\hline.$/ 14$. & $\cdot / r$ & $1 / 49$ & אזrא & r & $\cdot \mid \& \& V$ & مرحله & \multirow{2}{*}{ خودزنى } & \multirow{2}{*}{ آزمايش } \\
\hline & & & $\cdot / 109$ & 11 & T/AS & خطا & & \\
\hline.$/ 1 T$. & $\cdot / T \Delta$ & $\cdot / \Lambda$. & 㑭 & r &.$/ 9$. & مرحله & \multirow{2}{*}{ خودزنى } & \multirow{2}{*}{ كنترل } \\
\hline & & &.$/ 1 \wedge$ & 11 & $\Gamma / 90$ & خطا & & \\
\hline
\end{tabular}

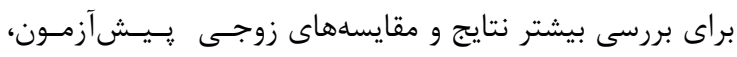

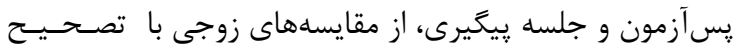
بنفرونى (جدول • (1) استفاده شده است.
نتايج جدول شماره نه، نشان مى دهد كه از بين سه مرحله اندازه

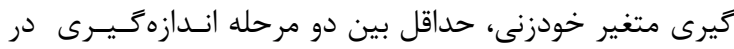

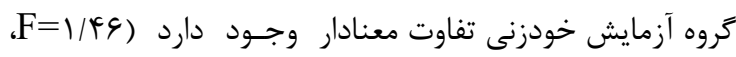
(P=./. $\mathrm{r}$

جدول •ا: نتايج آزمون تعقيبى بنفرنى براى مقايسه نمرات خودزنى بر حسب تروه هاى آزمايش و كنترل

\begin{tabular}{|c|c|c|c|c|}
\hline بيعيرى & يش آزمون & مراحله & كروه & متغير \\
\hline$\cdot \pi \cdot *$ & $.11 \cdot *$ & ييش آزمون & \multirow{2}{*}{ آزمايش } & \multirow{4}{*}{ خودزنى } \\
\hline$\cdot \pi$ & - & ِس آزمون & & \\
\hline.$/ 1$ & $\cdot 10$ & ييش آزمون & \multirow{2}{*}{ كنترل } & \\
\hline$\cdot . \cdot$ & - & ِسآزمون & & \\
\hline
\end{tabular}

ي يُيَيرى تفاوت معنادارى وجود دارد. در كروه كنترل، خـودزنسى

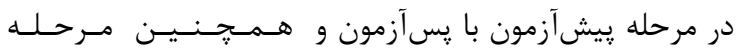
يِيش آزمون با جلسه يِيخيرى تفاوت معنادارى وجود ندارد.
بررسى نتايج آزمون تعقيبى در جدول شماره • ا، نشان مىدهد *** ك

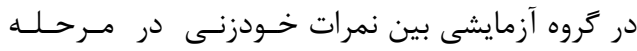

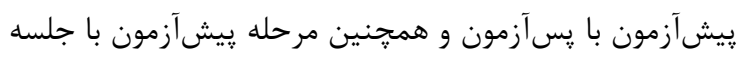


هيجانى، احساس ترك شدن، رفتار خودكشى و مشكلات هويتى

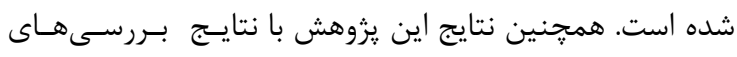

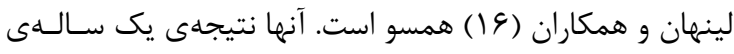

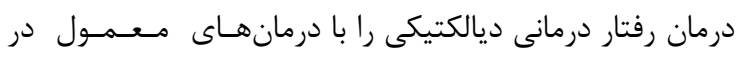

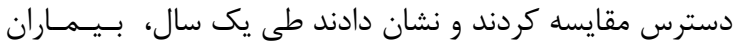

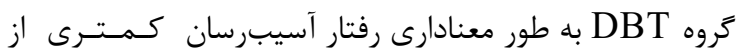

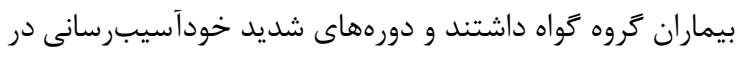

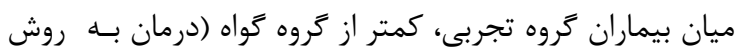

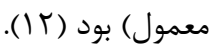

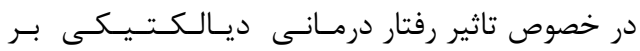

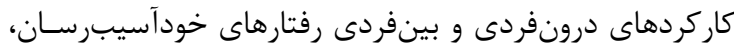

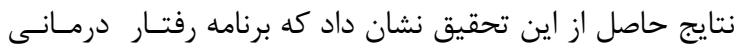

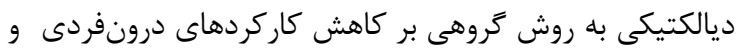

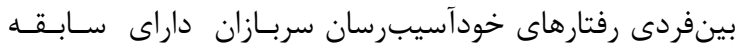

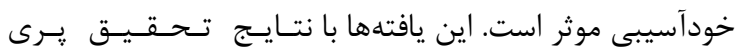

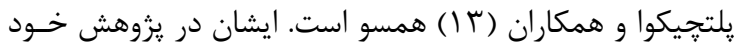

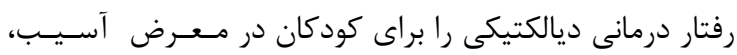

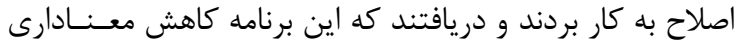

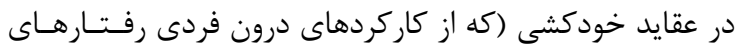

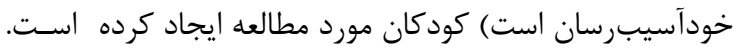

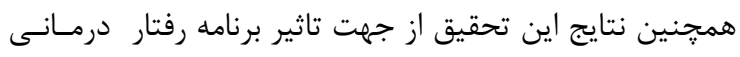

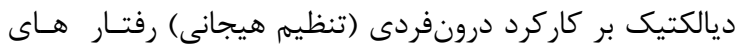

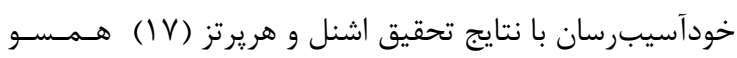

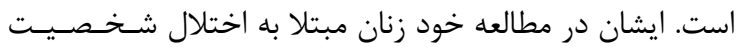

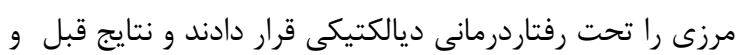

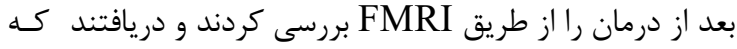

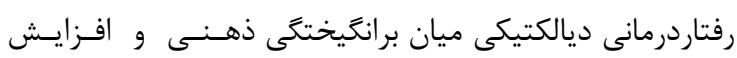

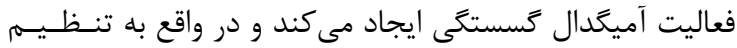

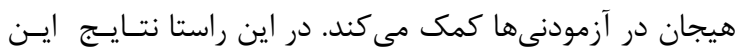

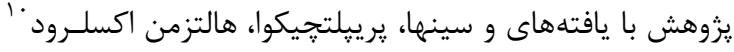

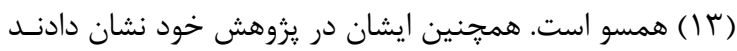

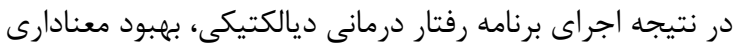

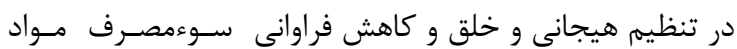
آزمودنى ها رخ داده است.

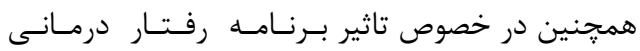

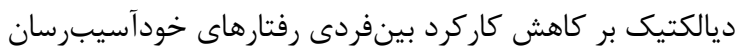

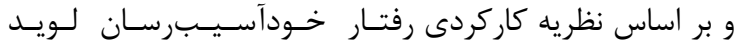

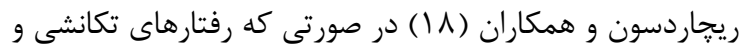

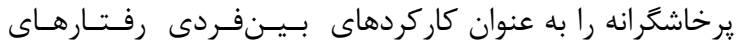

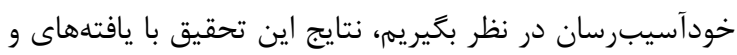

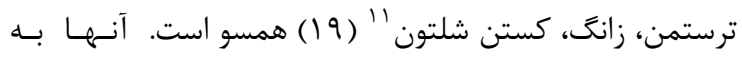

10- Prypltchikova, Haltzman, Axelrod 11- Trestman, Zang, Castan Shelton
بحث نتيجه

هدف يزوهش حاضر، بررسى اثربخشى رفتاردرمانى ديالكتيـكى دئى بر تنظيم هيجان و كنترل تكانش

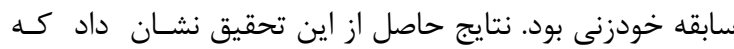

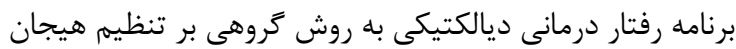

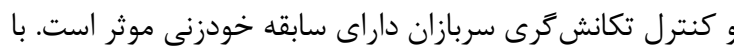

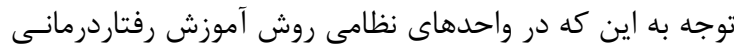

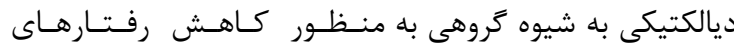

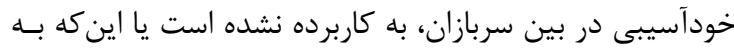

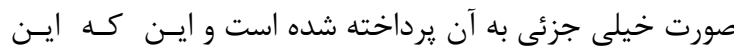

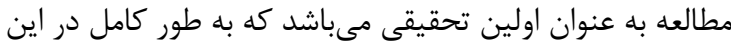
زمينه به صورت تخصصى بررسى دقيقى به عمل آورده است، لذا

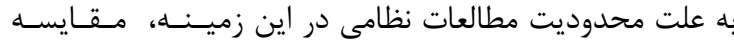

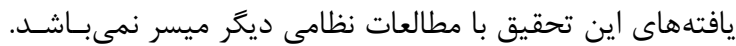

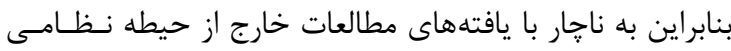
مقايسه مى تر دد. تحليل دادهها نشان داد كــه سربازان شركت كنــنده در در

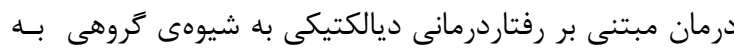

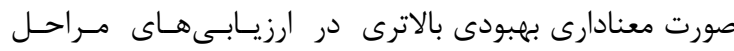

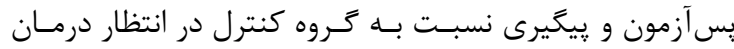

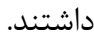

اين يافته با نتايج تحقيق فليس خاكـر و و هـــــــــاران،

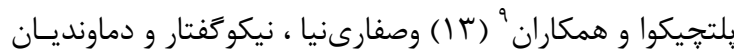

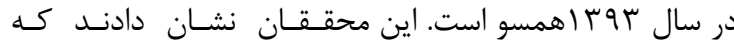

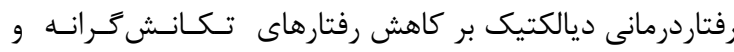

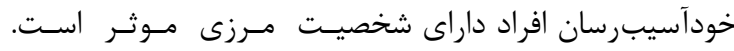

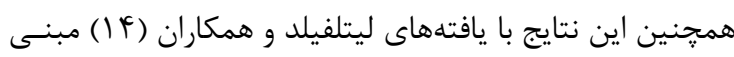

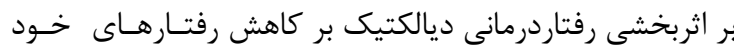

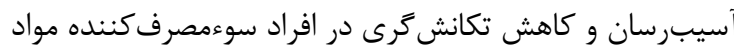

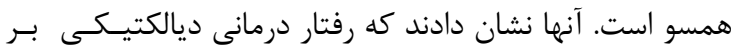

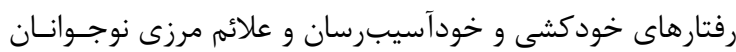

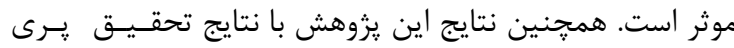

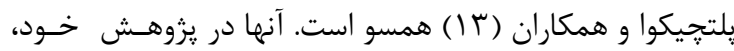

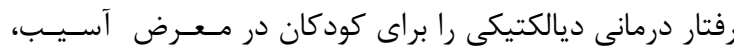

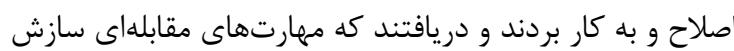

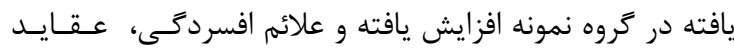

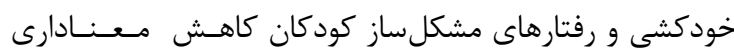

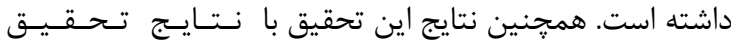

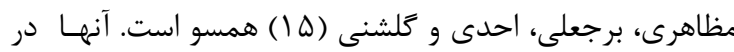

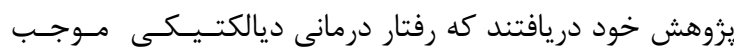

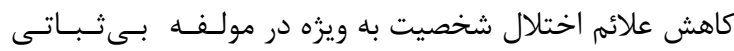

9- Felis Chucker et al., Peltchikova et al 
رفتارهاى خودآسيبرسان در سربازان خودآسيبرسان، مد نظــر

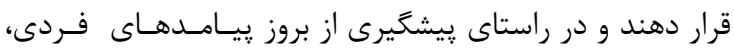

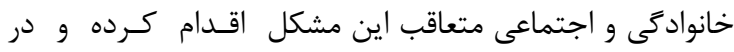

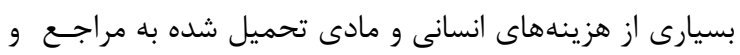
نهادهاى ذينفع صرفهجويى كنند.

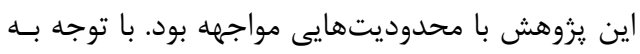

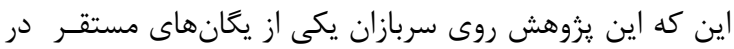

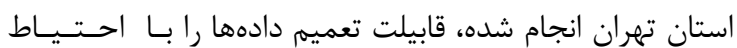

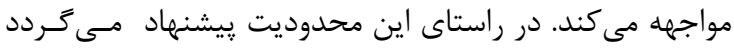

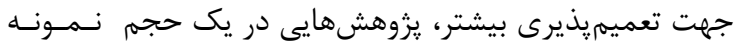

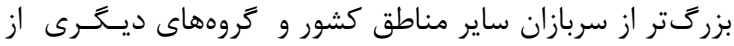
كاركنان نيروهاى مسلح مانند كاركنان بايور انجام شود.

\section{تشكر و قدر دانى}

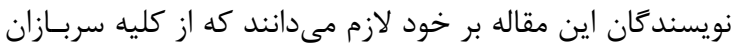

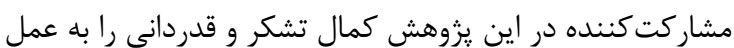

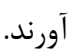

اصلاح روش رفتار درمانى ديالكتيكى به منظور استفـاده بـراى رئر

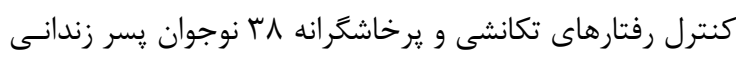

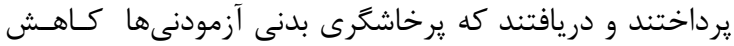

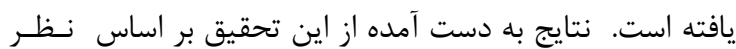

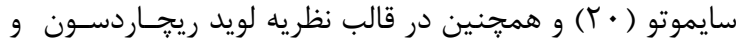

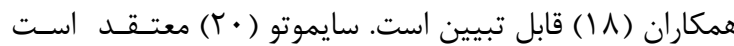

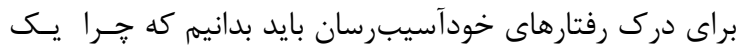

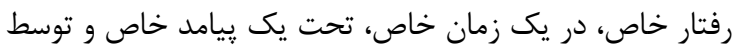

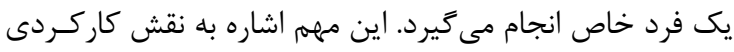

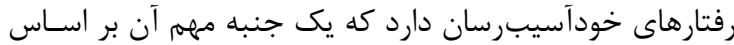

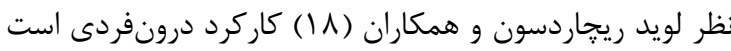

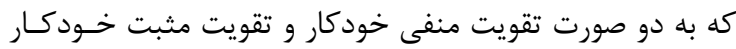

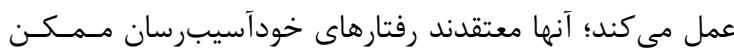

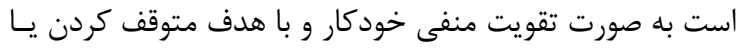

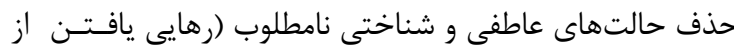

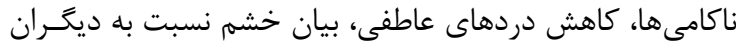

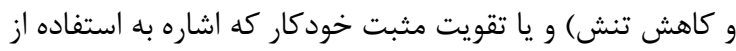

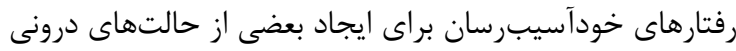

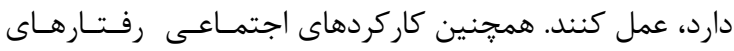

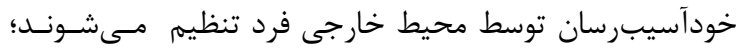

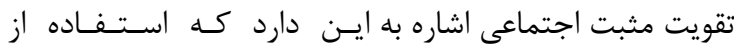
رفتارهاى خودآسيبرسان براى جلب توجه و يا براى دسترسى إنى به برخى از منابع خاص اجتماعى است.

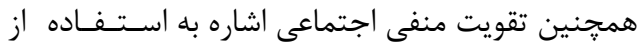

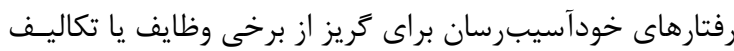

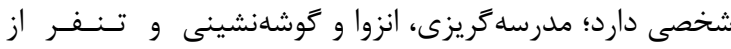

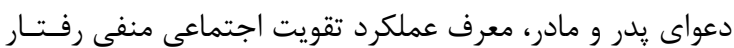
خودآسيبرسان است. لويد ريجاردسون و همكاران (1) (1).

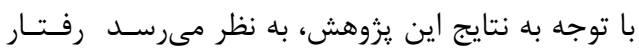

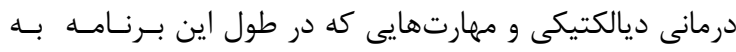

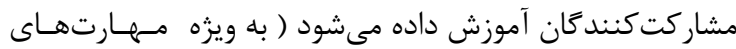

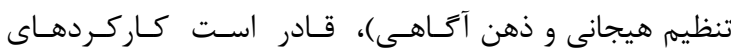

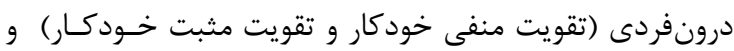

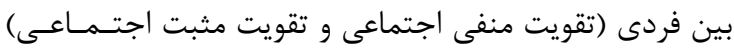

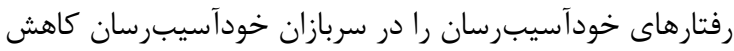

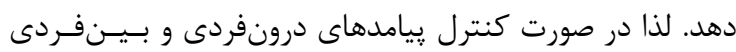

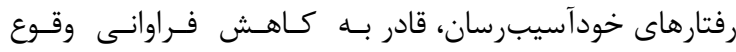

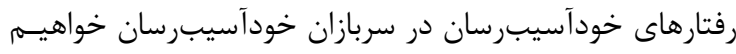

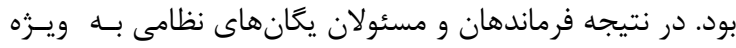

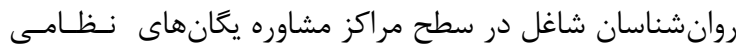

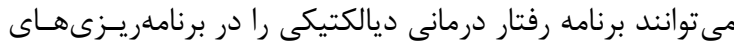

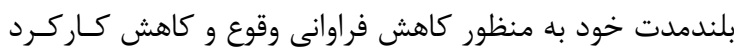




\section{References}

1- Afroozfar P, Hashemian M. A Study of Persian Equivalents for Compound Words in Psychology on the Basis of Translation Procedures Proposed by Vinay and Darbelnet. Modern Journal of Language Teaching Methods. 2017;7(2):94.

2- Klonsky ED. The functions of deliberate selfinjury: a review of the evidence. Clinical psychology review. 2007;27(2):226-239

3- Muehlenkamp JJ. Self-injurious behavior as a separate clinical syndrome. The American journal of orthopsychiatry. 2005; 75(2):324-333.

4- Linehan MM, Korslund KE, Harned MS, Gallop RJ, Lungu A, Neacsiu AD, et al. Dialectical behavior therapy for high suicide risk in individuals with borderline personality disorder: a randomized clinical trial and component analysis. JAMA psychiatry. 2015;72(5):82-475.

5- GratzKL,RoemerL.Multidimensional assessment of emotion regulation and dysregulation: Development, factor structure, and initial validation of the difficulties in emotion regulation scale. Journal of psychopathology and behavioral assessment. 2004;26(1):54-41

6- Lourie M, Rata E. A critique of the role of culture in Maori education. British Journal of Sociology of Education. 2014:35(1):36.

7- Akhavan, Shiva. Sajjadian, Illnaz (2016) The Effectiveness of Dialectical Behavior Therapy on Emotional and Impulsive

Instability in People with Bipolar Disorder. Journal of Clinical Psychology / Year 8 / Issue 3 (consecutive 31)

8- American Psychiatric Association (2013). DSM5 Diagnosis and Mental Disorders Guide. Yahya Seyed Mohammadi (2014). Psychological publication. P. 1005

9- Barratt Es. Impulsivity: integrating cognitive, behavioral. Biological and environmental data. American Psychological Association. 1994.

10- Garnovskii D, Kukushkin VY, Haukka M. Wagner., G.; Pombeiro. J Chem Soc, Dalton Trans. 2001;560:1.

11- Lourie M, Rata E. A critique of the role of culture in Maori education. British Journal of Sociology of Education. 2014;35(1):36-19.

12- Matthew McKay; Jeffrey Wood; Jeffrey Brentley (2007). Behavioral Therapy Techniques . Dr Hassan Hamidpour, Hamid Jomehpour and Dr Zahra Andouz (2012). Second Ch. Tehran .Arjmand

13- Fleischhaker $\mathrm{CH}$ BR, Sixt B, Bruck $\mathrm{CH}$, Schneider C, Schulz E. Dialectical Behavioral Therapy for adolescents (DBT-A): a clinical Trial for Patients with suicidal and self-injurious Behavior and Borderline Symptoms with a one-year Follow-up. 2011;38-5:33.

14- Lett HBJ, Babyak MA, Strauman TJ, Robins C, Sherwood A. Social support and coronary heart disease: epidemiologic evidence and implications for treatment. Psychosom Med. 2005;67(6):869-87 15- Ahmad Barjali, Mohammad Javad Begian Koule Marz, Mohammad Ali Yazdan Panah, Moslem Rajabi; (2015) The Effectiveness of Group Dialec- tical Behavioral Therapy (DBT) Training on Improving the Quality of Life and Reducing Impulsivity in Patients with Bipolar Disorder I. (1) Issue 20, Fifth Year, Fall 94

16- Linehan M. Cognitive-behavioral treatment of borderline personality disorder: Guilford press; 1993.

17- Schnell K, Herpertz, S.C. Effects of dialectical behavior therapy on the neural correlates of affective hyperarousal in borderline personality disorder. psychiatric research. 2006;41(10):48-837

18- Lloyd-Richardson EE, Perrine, N Dierker, L., \& Kelley, M. L. Characteristics and functions of non-suicidal self-injury in a community sample of adolescents. Psychological Medicine. 2007;. 9237:1183

19- Zhang HW, SR. Bauer, MS. . Comparison of perceived quality of life across clinical states in bipolar disorder: Data from first 2000 Systematic Treatment Enhancement Program For bipolar Disorder STEP-BD participants. Compr Psychiatry. 2006;. 8-47:161.

20- Suymoto KL. The functions of self-mutilation. Clinical Psychology Review. 1998;.54-18:531. 